\title{
Relationship problems between doctors and paramedical professionals working in leprosy with reference to a possible solution
}

\author{
R PREMKUMAR* \& S DAVE† \\ * Schieffelin Leprosy Research and Training Centre, Karigiri 632 \\ 106, N.A.A. Dist., India; and †Department of Public Administra- \\ tion, Nagpur University, Nagpur, India
}

\section{Accepted for publication 18 September 1991}

\begin{abstract}
Summary An empirical investigation was conducted on the in-group dynamics of health personnel working in leprosy. The sample populations were taken from the National Leprosy Eradication Programme (NLEP) employees of two state governments in India. They consisted of 21 doctors and 335 paramedicals, the former constituting a formal group and the latter a semiformal group. Two separate scales were developed for each of these groups to elicit information on five potential areas of intergroup relationships.

The results indicated that there was very poor acceptance of the out-group and its roles, i.e. poor acceptance of the paramedicals by the doctors and vice versa. Three reasons were elicited from this study. First, doctors held their professional standing to be on a higher level than the paramedicals, leading to excessive social distancing between doctors and paramedicals. Second, multiprofessional involvement in NLEP work has increased the trend of professional overlapping, leading to a significant apprehension of the encroachment of skills. Third, there was a mutual lack of trust of each others professional skills. Despite these problems the otherwise more severe human relationship problems, such as domineering behaviour and prejudiced perception against the out-group were found to be significantly less in this study.

In order to improve working relationships between these groups a method that has been used at Karigiri is recommended. The method has two parts. The first is aimed at intrapersonal understanding and the second at the development of interpersonal skills. Role play that mimics their original work situation and an analysis of case histories were the methods of teaching that were found to be more advantageous in internalizing these skills.
\end{abstract}

\section{Introduction}

To control leprosy, the National Leprosy Eradication Programme (NLEP) in India has employed a significant number of professionally trained health personnel, such as medical 
officers and paramedical professionals. These employees are directly involved in patient care activities that consist of prevention, treatment, education and rehabilitation of leprosy patients.

Medical officers are identified as a recognized prestigious occupational group. Paramedical staff are also adequately trained in their area of health, however they are of a lower power professional group in comparison to doctors. Among these two groups, medical officers are formal, while paramedicals are semi-formal in nature and each belongs to their own professional group on the basis of economic and intellectual needs. The study considers this as in-group dynamics. Anyone who does not share these needs is seen as 'out-group' by the 'in-group'.

Good intrapersonal relationships between these two major professional groups will open up a two-way communication, and provide support to each others professional skills, utimately facilitating an environment that is conducive for ideal leprosy control work. This study has focused on five potential areas which can assist or affect intergroup relationships amongst medical and paramedical professionals. The relevant data to analyse these aspects was obtained from the health professionals by asking them to evaluate their own role and the role of the other professional group, with the assistance of two scales developed for this purpose.

\section{Materials and methods}

\section{SAMPLE}

The health care system taken for analysis was the NLEP of two state governments in India. The health personnel of NLEP were selected from one district in Andhra Pradesh (AP), and one in Tamil Nadu (TN), consisting of a total sample population of 356 . For the analysis of inter-group behaviour, the sample population was divided up in one or two of the following ways, on the basis of the social identity construction of Rey-Kowshiki. ${ }^{1}$

The total sample population of 356 NLEP health personnel formed one group from the sample districts.

2 The sample population was also split into two groups depending on whether they had professional medical qualifications (21) or allied health professional qualifications (335). The allied health professionals included nurses, laboratory technicians (LT), leprosy physiotherapy technicians (PT), health educators (HE), non-medical supervisors (NMS), pharmacists (Pharm) and the leprosy field workers known as leprosy inspectors (LI) in TN and nonmedical assistants (NMA) in AP.

Cluster sampling was used in this study by selecting the whole of each of the above two districts as clusters. The reason being that at the district level the NLEP consists of units such as leprosy control units, survey-education-treatment centres and temporary hospitalization wards. Collecting data from all these units is possible through cluster sampling, which results in a uniform pattern of information and recording.

\section{SCALE OF ASSESSMENT}

Two scales of assessment were constructed to evaluate mutual perception of medical and paramedical professionals. The data were collected using a scale developed by the 
researcher based on the perception-attitude-behaviour (PAB) concept. The scale consisted of 19 variable test items (Table 1). Mutual perception of medical and paramedical professionals was one of the variables. This consisted of two scales of 5 statements each, to elicit $\mathrm{PAB}$ responses from doctors and the same number for paramedicals (Appendix 1 and 2). Two statements in it were phrased positively and the remaining 3 negatively. A specific prepilot analysis of the NLEP organizational climate conducted by the researcher helped to identify the following 5 potential areas which can assist or affect intergroup relationships between medical and paramedical professionals:

1 Professional overlapping: paramedicals, encroaching on the doctors area of specalization and vice versa.

2 Social distancing due to occupational prestige.

3 Mutual trust or mistrust towards each others professional skills.

4 Mutual professional support or prejudiced behaviour.

5 Participative attitude or a domineering attitude towards the out-group.

To elicit the attitude of the sample population in the above-mentioned areas, appropriate statements in accordance with their job descriptions were used (Appendices 1 and 2).

Table 1. Coefficient ranking of variables

\begin{tabular}{|c|c|c|c|c|c|c|}
\hline S. No. & Variables & $\mathrm{N}$ & Mean & SD & $\begin{array}{l}\text { Coefficient } \\
\text { of variations }\end{array}$ & Position \\
\hline 1 & Mutual perception of & 356 & 2.43 & 0.72 & 29.63 & 19 \\
\hline \multirow[t]{2}{*}{2} & Interaction of health & & & & & \\
\hline & professionals with admin staff & 356 & $2 \cdot 49$ & $0 \cdot 63$ & $25 \cdot 30$ & 9 \\
\hline 3 & Supervisory behaviour & 62 & $2 \cdot 83$ & $0 \cdot 76$ & $26 \cdot 86$ & 16 \\
\hline 4 & $\begin{array}{l}\text { Health professionals-leprosy patients } \\
\text { relationship }\end{array}$ & 356 & $2 \cdot 58$ & $0 \cdot 71$ & $27 \cdot 52$ & 17 \\
\hline 5 & Autonomy & 356 & $2 \cdot 95$ & $0 \cdot 62$ & $21 \cdot 01$ & 2 \\
\hline \multirow[t]{2}{*}{6} & Subordinate description & & & & & \\
\hline & of supervisory, behaviour & 356 & $2 \cdot 39$ & $0 \cdot 67$ & $28 \cdot 03$ & 18 \\
\hline 7 & Pay satisfaction & 356 & $2 \cdot 70$ & $0 \cdot 72$ & $26 \cdot 67$ & 14 \\
\hline 8 & Skill utilization & 356 & $2 \cdot 77$ & $0 \cdot 69$ & $24 \cdot 91$ & 8 \\
\hline 9 & Organizational climate & 356 & $2 \cdot 84$ & $0 \cdot 63$ & $22 \cdot 18$ & 6 \\
\hline 10 & Job significance within the community & 356 & $2 \cdot 57$ & $0 \cdot 68$ & $26 \cdot 46$ & 12 \\
\hline 11 & Promotion satisfaction & 356 & $2 \cdot 91$ & $0 \cdot 78$ & $26 \cdot 80$ & 15 \\
\hline \multirow[t]{2}{*}{12} & Adjustment pattern & & & & & \\
\hline & to the disease & 356 & $2 \cdot 30$ & $0 \cdot 59$ & $25 \cdot 65$ & 13 \\
\hline 13 & Organizational commitment & 356 & $3 \cdot 06$ & 0.67 & $21 \cdot 90$ & 5 \\
\hline 14 & Skill variety & 356 & $3 \cdot 03$ & $0 \cdot 66$ & $21 \cdot 78$ & 4 \\
\hline \multirow[t]{2}{*}{15} & Adjustment pattern to & & & & & \\
\hline & the nature of work & 356 & $2 \cdot 43$ & $0 \cdot 62$ & $25 \cdot 51$ & 11 \\
\hline & Skill development 6 & 356 & $3 \cdot 09$ & $0 \cdot 52$ & $16 \cdot 82$ & 1 \\
\hline \multirow[t]{2}{*}{17} & Job significance within & & & & & \\
\hline & the organization & 356 & $2 \cdot 71$ & $0 \cdot 69$ & $21 \cdot 46$ & 10 \\
\hline \multirow[t]{2}{*}{18} & Interdepartmental & & & & & \\
\hline & relations & 356 & $2 \cdot 95$ & 0.63 & $21 \cdot 36$ & 3 \\
\hline 19 & Technical satisfaction & 356 & $2 \cdot 74$ & $0 \cdot 66$ & $24 \cdot 09$ & 7 \\
\hline
\end{tabular}




\section{SCORING SYSTEM}

The content analysis of the responses from the sample served as the source of data pool. The intercorrelation of factors to this variable with other variables was $r=0 \cdot 001$. The internal consistency of the PAB scale was obtained by correcting $r$ with the 'KR-21 formula' $r=1 \cdot 00$.

The Likert scale as modified by Vasudeva ${ }^{2}$ was used in scoring the PAB scale. It consists of a 6-point response instead of the 5-point response of the original Likert scale. These were: strongly agree (SA); agree (A); mildly agree (MA); mildly disagree (MD); disagree (D), and strongly disagree (SD). Thus it eliminated the possibility of the undecided response of the 5 point Likert scale, forcing the candidate to either accept or reject the statement. One study ${ }^{3}$ has stated that the 'Don't know' category has been a source of difficulty and controversy in many fields of psychological research. The scoring for the 2 positive statements were as follows: SD $-0, \mathrm{D}-1, \mathrm{MD}-2, \mathrm{MA}-3, \mathrm{~A}-4$ and $\mathrm{SA}-5$. For the 3 negative statements this scoring was reversed.

Results were obtained by using three tests, namely: (a) the co-efficient of variation test; (b) the two-tail test for the level of significance; and (c) the computation of frequency of response.

\section{Results}

1 Mutual perception of medical and paramedical professionals was rated last (19th) in the coefficient ranking of the variable test $(\mathrm{N}=356 ;$ mean $=2.43 ; \mathrm{SD}=0.72$ and coefficient of variations $=23.63$ ) (Table 1). It indicated that there was a very poor acceptance of the out-group and their roles.

2 Further analysis was made to find out whether there was any significant difference betwen the medical and paramedical professionals in the in-group and out-group discriminatory behaviour (Table 2). The results showed no significant difference. This indicated that the level of discriminatory behaviour between the two groups was similar. 3 The computation of frequency of response revealed that three potential areas of intergroup relationships were significantly affected (Table 3). These were (a) social distancing by doctors due to occupational prestige $(71.4 \%)$; (b) mutual lack of trust toward each others professional skills (62.1\%); and (c) mutual perception of professional

Table 2. Comparison of mutual perception of medical and paramedical professionals

\begin{tabular}{|c|c|c|c|c|c|c|c|c|c|c|}
\hline \multirow[b]{2}{*}{ Profession } & \multirow[b]{2}{*}{$\mathrm{N}$} & \multirow[b]{2}{*}{ Mean } & \multirow[b]{2}{*}{ SD } & \multirow[b]{2}{*}{ SEr } & \multirow[b]{2}{*}{$\mathrm{F}$} & \multirow[b]{2}{*}{$P$} & \multicolumn{4}{|c|}{ Pooled variance estimate } \\
\hline & & & & & & & $\mathrm{t}$ & df & 2-tail & $\begin{array}{c}\text { Significant/ } \\
\text { not significant }\end{array}$ \\
\hline Doctor & 21 & $2 \cdot 69$ & $0 \cdot 35$ & 0.076 & 4.48 & $0.000^{*}$ & 1.67 & 354 & 0.095 & NS \\
\hline Paramedical & 335 & $2 \cdot 41$ & $0 \cdot 74$ & $0 \cdot 040$ & & & & & & \\
\hline
\end{tabular}

* Significance level of $\mathrm{F}$ value is large. Therefore pooled variance 2-tail probability estimate was used in this analysis. 
Table 3. Frequency of response

\begin{tabular}{|c|c|c|c|c|c|c|c|c|c|c|c|c|c|c|c|c|c|c|c|c|c|c|}
\hline \multirow[b]{2}{*}{ Nos } & \multirow{2}{*}{$\begin{array}{l}\text { Statement } \\
\text { No. in the } \\
\text { schedule }\end{array}$} & \multicolumn{6}{|c|}{ Among the total sample } & \multirow[b]{2}{*}{ Total } & \multicolumn{6}{|c|}{ Among doctors } & \multirow[b]{2}{*}{ Total } & \multicolumn{6}{|c|}{ Among paramedicals } & \multirow[b]{2}{*}{ Total } \\
\hline & & 0 & 1 & 2 & 3 & 4 & 5 & & 0 & 1 & 2 & 3 & 4 & 5 & & 0 & 1 & 2 & 3 & 4 & 5 & \\
\hline 1 & 18 & 33 & 81 & 24 & 42 & 111 & 65 & 356 & 0 & 3 & 4 & 5 & 6 & 3 & 21 & 33 & 78 & 20 & 37 & 105 & 62 & 335 \\
\hline 2 & 36 & 28 & 97 & 25 & 56 & 111 & 35 & 356 & 0 & 5 & 1 & 0 & 10 & 5 & 21 & 28 & 92 & 24 & 56 & 101 & 30 & 331 \\
\hline 3 & 54 & 31 & 127 & 60 & 33 & 64 & 36 & 351 & 1 & 8 & 7 & 2 & 2 & 0 & 20 & 30 & 119 & 53 & 31 & 62 & 36 & 331 \\
\hline 4 & 72 & 22 & 79 & 15 & 49 & 155 & 33 & 353 & 1 & 0 & 1 & 3 & 14 & 2 & 21 & 21 & 79 & 14 & 46 & 141 & 31 & 332 \\
\hline 5 & 90 & 67 & 167 & 54 & 8 & 41 & 16 & 353 & 3 & 11 & 3 & 1 & 3 & 0 & 21 & 64 & 156 & 51 & 7 & 38 & 16 & 332 \\
\hline
\end{tabular}

overlapping (61·2\%). However, a domineering attitude and prejudiced behaviour toward the out-group were significantly less (18.3\% and $32.8 \%$, respectively).

\section{Discussion}

The above finding is not surprising and has been reported earlier by members of the medical professions in general practice. ${ }^{4-7}$ Therefore, in this discussion an attempt has been made to explain the three problem areas in human relationships as elicited in this study, in comparison with earlier works.

As far as paramedicals are concerned one $s t u d y^{8}$ has pointed out that working beside a physician may be acceptable to paramedicals, but working in a subsidiary relationship to a physician is not. A further study ${ }^{9}$ is also of the same opinion and pointed out that the new generation of allied health professionals expect to be treated with the respect that their professional training has earned for them. They are less likely to carry out doctor's orders without question than was formerly the case. For example, physiotherapy education emphasizes a cooperative team approach to physical treatment. ${ }^{10}$ It has been noted $^{11}$ that pharmacists hold similar expectations. New curricula in nursing particularly stresses the importance of nurses being able to meet a patient's psychosocial needs, solve clinical problems, generate problem-oriented nursing plans and act as patients' advocates. ${ }^{12}$ Such a trend elevates the allied health professional from the level of an ancillary staff to a therapist status.

At the same time, paramedicals were aware of the existing norms of belonging to a lower professional group in comparison to the doctors. Second, professional ethics forced them to accept the doctor to be the leader of the team. For any professional, interference or orders from an out-group can become a sensitive issue. This conflict between their actual role and their group expectations leads to an attitude of less trust of doctors.

Looking at the problem from the doctors point of view, their professional standing leads them to maintain a certain level of social distance from allied health professionals in the work situation, when both these groups interact in leader-subordinate roles. However, excessive social distancing affects the social ties that draw both these groups together. The results of this study showed that a significant percentage $(71.4)$ of doctors were strongly inclined toward maintaining such a social distance. At the same time a significant number of allied health personnel perceived such distancing negatively $(56 \cdot 5 \%)$.

Also, to a certain extent the comparison of work experience between these health 
professionals explains the lack of trust doctors have toward paramedicals. Most of the paramedicals in NLEP were exclusively recruited to work in leprosy, whereas the medical officers were transferred from general medical care to work in leprosy. Among the sample population, only $35 \%$ of doctors in comparison to $46 \%$ of paramedicals had more than 5 years experience in the field of leprosy. Similarly, only $20 \%$ of doctors had more than 10 years of experience in NLEP, whereas $47 \%$ of paramedicals had more than 10 years. In such a situation, the experienced paramedicals let the doctors know that they do not appreciate them meddling in their area of work because they feel that they have far more experience of leprosy than the doctors. This results in a passive attempt not to accept the domination of the high-powered group. When doctors find it difficult to exercise the "team leader approach', it leads to frustration and results in a lack of trust in paramedicals.

Regarding professional overlapping in the NLEP, seven paramedical professionals and a doctor are involved in a patient care activities. With so many professionals being involved together in leprosy work the situation of overlapping can very easily be perceived. It can naturally produce apprehension among doctors if they feel that paramedicals are encroaching upon their specialization and vice versa.

Despite these relationship problems, it is heartening to note that the NLEP organization is less significantly affected by the other two more severe forms of human relation problems, such as a domineering attitude and prejudiced behaviour towards an out-group.

\section{AN ALTERNATE PERSPECTIVE}

In recent times attempts have been made to promote and strengthen the relationship between the health personnel and the community. Similarly, the relationship amongst health workers is also equally important. Improved relationships will positively affect worker performance and programme implementation. One study ${ }^{13}$ pointed out that not teaching about working relationships during medical training led to management by imitation, with the younger physicians mimicking the behaviour of their more experienced peers.

Since 1987 the researcher has been conducting sessions on 'working relationships' during the management and health education modules. These were conducted for health professionals, as part of their postbasic training in leprosy at the Schieffelin Leprosy Research and Training Centre, Karigiri, India. The sessions were conducted in a homogeneous group situation. The participants were either medical officers or nonmedical supervisors.

The content of these sessions were divided into two parts. The first aimed at intrapersonal understanding; a 2-hour session was marked for this in the management module. In this session attempts were made to uncover the basis of out-group bias. For this purpose, feedback about profession-based self-concept was elicited by administering the PAB rating scale developed for this study on the participants (Appendix 1 and 2). Profession based self-concept is the most important single factor that affects communication with others. They scored themselves with the key given by the trainer. This exercise was followed by lecture/discussion to further develop intraunderstanding about themselves and to perceive accurately how others are reacting to one's own behaviour.

The second part was on development of interpersonal skills. It involved listening, understanding and communicating. ${ }^{14}$ The main objective of the health education module is to learn these three skills and to apply them in their patient and community work. These 
principles also apply to interpersonal relationships with colleagues, subordinates and supervisors. Two methods of teaching were used, namely, role play and analysis of case histories. The feedback from the role play was used to create awareness about their own style of listening and communication. Initially we used a rating scale for this purpose. Along with the rating scale, we have introduced video recordings, which were taken during the role play and these were used for further recall, thus developing performance.

To understand why the patient and community decide to behave the way they do, analysis of case histories were used. This can also produce awareness in understanding certain behaviour in the other professional group. This session was conducted as group work and the members do group reporting. In the plenary session desirable and undesirable behaviour are analysed and attempts are made to understand these from the psychosocial perspective of the patient and community. Approximately 10 hours were allotted for developing interpersonal skills. These sessions progressed at a speed set by the participants. There is no long-term follow-up report on the outcome of such sessions; however, the postmodule feedback session showed that there was initial uncertainty and anxiety when their intrapersonal and interpersonal styles were exposed in the feedback. Gradually most of the participants settled down and found the exercise useful.

We do recognize the limitations of the above relearning processes as relationship building is controlled by several environmental factors, such as organizational climate and the basic personality of the individuals. The personnel are also controlled by behaviour pattern set by the 'in' and 'out' professional groups and are subjected to pressure exerted by these groups. To change this group behaviour, we recommend that the issue of mutual interdependence and respect of other health professional skills should be addressed at a basic level in medical and allied education. This process may need to be relearned from time to time as part of ref resher or postbasic training. In this way it will become an established norm, thus creating an ideal working environment.

\section{Acknowledgment}

This study is a part of the doctoral thesis of Mr R Premkumar, submitted to the Faculty of Social Sciences, Nagpur University, Nagpur, India.

We wish to thank Mrs Judy Satish and Dr Sujai Suneetha for their assistance in the preparation of the manuscript and Mrs Glory Davidson for typing.

\section{References}

1 Rey-Kowshiki J. Ann Rev Psychol, 1982; 33: 123-54.

2 Vasudeva. Social change. An analysis of attitude and personality. New Delhi: Sterling Publications, 1977.

3 Woodworth RS, Schlosberg H. Experimental psychology. London: Methuen, 1955.

4 Bradshaw JS. Doctor on trial. London: Wildwood House, 1978.

${ }^{5}$ McKeown T. The role of medicine; dream, mirage or nemesis? The Nuffield Provincial Hospitals Trust Publication, Nutfield, Australia, 1976.

6 Shapiro M. Getting doctored between the lines. Chicago Publications, 1978.

7 Taylor R. Medicine out of control. The anatomy of malignant technology. Melbourne: Sun Books, 1979.

8 Older J. Point of view-medics and paramedics. Anzame Bull, 1983; 4: 21.

9 Bates B. Doctor and nurse changing roles and relations. New' Eng J Med, 1970; 283: 129-34.

10 Twomey L. What I wish I could tell doctors. Register of members in private practice 1983-1984. NSW: Australian Physiotherapy Association, 1983. 
11 Oscar G. Physician and pharmacist - natural partners Australian Family Physician, 1981; 10: 866-970.

12 Ewan CE, White R. Teaching nursing-a self-instructional handbook. London: Cromm Helm, 1984.

13 Vogt FJ, Cox JA, Velthhouse BV, Thames BA. Retaining professional nurses. London: C.V. Mosby Company, 1983.

14 Marchais Des JE, Gastonguay PJ, Gastonguay LG. Training psychiatrists and family doctors in evaluating interpersonal skills. Med Educ, 1990; 24: 376-81.

15 Van Parijs LG. Hand-outs of the training of trainers in the health education and psycho-social aspects of leprosy, Bangalore, India, February 4-16, 1991.

16 Van Parijs LG. The trainer's guide in health education in leprosy work. London: ILEP, 1987.

\section{APPENDIX 1}

\section{Mutual perception of medical and paramedical professionals (MPMP) scale}

Statement to all the medical professionals in the sample

\begin{tabular}{|c|c|c|c|c|}
\hline S. No. & Factor & Statement loaded with factor & $\begin{array}{l}\text { Statement } \\
\text { No. in the } \\
\text { schedule }\end{array}$ & $\begin{array}{l}\text { Kind of } \\
\text { statement }\end{array}$ \\
\hline 1 & $\begin{array}{l}\text { Fear behaviour about the } \\
\text { paramedicals encroaching upon } \\
\text { their job. }\end{array}$ & $\begin{array}{l}\text { PMWs and NMS develop inflated ideas } \\
\text { of their own capacity and try to do the } \\
\text { doctor's job. }\end{array}$ & 18 & Negative \\
\hline 2 & $\begin{array}{l}\text { Attitude of maintaining social } \\
\text { distance. }\end{array}$ & $\begin{array}{l}\text { A medical officer is a medical officer } \\
\text { everywhere. He should maintain his } \\
\text { official dignity always. }\end{array}$ & 36 & Negative \\
\hline 3 & $\begin{array}{l}\text { Trust behaviour towards the skills } \\
\text { of the paramedicals. }\end{array}$ & $\begin{array}{l}\text { Doctors can trust the smear reports given } \\
\text { by the technicians. }\end{array}$ & 54 & Positive \\
\hline 4 & $\begin{array}{l}\text { Prejudiced perception about } \\
\text { paramedicals. }\end{array}$ & $\begin{array}{l}\text { PMWs are capable of detecting leprosy } \\
\text { and handling the condition when it is not } \\
\text { complicated. }\end{array}$ & 72 & Positive \\
\hline 5 & $\begin{array}{l}\text { Domineering attitude towards } \\
\text { paramedicals. }\end{array}$ & $\begin{array}{l}\text { Paramedical professions can only have a } \\
\text { limited influence on the final decision of } \\
\text { patient management. }\end{array}$ & 90 & Negative \\
\hline
\end{tabular}




\section{APPENDIX 2}

\section{Mutual perception of medical and paramedical professionals (MPMP) scale}

Statement to paramedical professionals

\begin{tabular}{|c|c|c|c|c|c|}
\hline S. No. & Factor & $\begin{array}{l}\text { Profession to } \\
\text { whom the } \\
\text { statement is } \\
\text { directed to }\end{array}$ & Statement loaded with factor & $\begin{array}{l}\text { Statement } \\
\text { No. in the } \\
\text { schedule }\end{array}$ & $\begin{array}{l}\text { Kind of } \\
\text { statement }\end{array}$ \\
\hline \multirow[t]{8}{*}{1} & \multirow[t]{8}{*}{$\begin{array}{l}\text { Attitude of the } \\
\text { paramedicals wanting } \\
\text { to encroach upon } \\
\text { MO's specialization. }\end{array}$} & NMS & $\begin{array}{l}\text { Consulting a doctor in leprosy is not } \\
\text { essential, because NMS can classify and } \\
\text { treat leprosy effectively. }\end{array}$ & 18 & Negative \\
\hline & & $\mathrm{HE}$ & $\begin{array}{l}\text { Consulting the MO regarding health } \\
\text { education activities is not essential because } \\
\text { health educators can decide and conduct } \\
\text { programmes. }\end{array}$ & & \\
\hline & & LI $(\mathrm{TN})$ & $\begin{array}{l}\text { Consulting a doctor in leprosy is not } \\
\text { essential because LIs can classify and treat } \\
\text { leprosy effectively. }\end{array}$ & & \\
\hline & & NMA (AP) & $\begin{array}{l}\text { Consulting a doctor in leprosy is not } \\
\text { essential because NMAs can classify and } \\
\text { treat leprosy effectively. }\end{array}$ & & \\
\hline & & PT & $\begin{array}{l}\text { Prescription for physiotherapy by MO is } \\
\text { not essential because physios can decide } \\
\text { themselves what treatment to give. }\end{array}$ & & \\
\hline & & LT & $\begin{array}{l}\text { Consulting the MO regarding repeat } \\
\text { smears is not essential because lab. } \\
\text { technicians can decide. }\end{array}$ & & \\
\hline & & Nurse & $\begin{array}{l}\text { Consulting the MO regarding patient care } \\
\text { is not essential because nurses can decide } \\
\text { effectively }\end{array}$ & & \\
\hline & & Pharm & $\begin{array}{l}\text { Consulting the MO in leprosy is not } \\
\text { essential because pharmacists can easily } \\
\text { prescribe these medicines. }\end{array}$ & & \\
\hline \multirow[t]{8}{*}{2} & \multirow{8}{*}{$\begin{array}{l}\text { Trust behaviour } \\
\text { towards the skills } \\
\text { of the MOs }\end{array}$} & NMS & $\begin{array}{l}\text { Compared with NMS, the MOs know } \\
\text { leprosy very well and are capable people. }\end{array}$ & \multirow[t]{8}{*}{54} & \multirow[t]{8}{*}{ Positive } \\
\hline & & $\mathrm{HE}$ & $\begin{array}{l}\text { Compared with HE the MOs know } \\
\text { leprosy very well and are capable people }\end{array}$ & & \\
\hline & & $\mathrm{LI}(\mathrm{TN})$ & $\begin{array}{l}\text { Compared with LI, the MOs know } \\
\text { leprosy very well and are capable people. }\end{array}$ & & \\
\hline & & NMA (AP) & $\begin{array}{l}\text { Compared with NMA, the MOs know } \\
\text { leprosy very well and are capable people. }\end{array}$ & & \\
\hline & & PT & $\begin{array}{l}\text { Compared with physios, the MOs know } \\
\text { leprosy very well and are capable people. }\end{array}$ & & \\
\hline & & LT & $\begin{array}{l}\text { Compared with Lab. Technicians, the } \\
\text { MOs knows leprosy very well and are } \\
\text { capable people. }\end{array}$ & & \\
\hline & & Nurse & $\begin{array}{l}\text { Compared with nurses, the MOs know } \\
\text { leprosy very well and are capable people. }\end{array}$ & & \\
\hline & & Pharm & $\begin{array}{l}\text { Compared with pharmacists, the MOs } \\
\text { know leprosy very well and are capable } \\
\text { people. }\end{array}$ & & \\
\hline
\end{tabular}


Appendix 2 (continued)

\begin{tabular}{|c|c|c|c|c|c|}
\hline S. No. & Factor & $\begin{array}{l}\text { Profession to } \\
\text { whom the } \\
\text { statement is } \\
\text { directed to }\end{array}$ & Statement loaded with factor & $\begin{array}{l}\text { Statement } \\
\text { No. in the } \\
\text { schedule }\end{array}$ & $\begin{array}{l}\text { Kind of } \\
\text { statement }\end{array}$ \\
\hline \multirow[t]{8}{*}{3} & \multirow[t]{8}{*}{$\begin{array}{l}\text { Perception about } \\
\text { social distance of MOs. }\end{array}$} & NMS & $\begin{array}{l}\text { The MOs are proud people who maintain } \\
\text { a certain distance from NMS. }\end{array}$ & \multirow[t]{8}{*}{36} & \multirow[t]{8}{*}{ Negative } \\
\hline & & HE & $\begin{array}{l}\text { The MOs are proud people who maintain } \\
\text { a certain distance from health educators. }\end{array}$ & & \\
\hline & & LI (TN) & $\begin{array}{l}\text { The MOs are proud people who maintain } \\
\text { a certain distance from LIs }\end{array}$ & & \\
\hline & & NMA (AP) & $\begin{array}{l}\text { The MOs are proud people who maintain } \\
\text { a certain distance from NMAs }\end{array}$ & & \\
\hline & & $\mathrm{PT}$ & $\begin{array}{l}\text { The MOs are proud people who maintain } \\
\text { a certain distance from Physios. }\end{array}$ & & \\
\hline & & LT & $\begin{array}{l}\text { The MOs are proud people who maintain } \\
\text { a certain distance from Lab. Technicians. }\end{array}$ & & \\
\hline & & Nurse & $\begin{array}{l}\text { The MOs are proud people who maintain } \\
\text { a certain distance from nurses. }\end{array}$ & & \\
\hline & & Pharm & $\begin{array}{l}\text { The MOs are proud people who maintain } \\
\text { certain distance from pharmacists. }\end{array}$ & & \\
\hline 4 & $\begin{array}{l}\text { Prejudiced percetion } \\
\text { about MOs. }\end{array}$ & ALL & $\begin{array}{l}\text { At times it is difficult to think that doctors } \\
\text { in a control unit are equal to doctors in } \\
\text { general practice }\end{array}$ & 72 & Negative \\
\hline \multirow[t]{8}{*}{5} & \multirow[t]{8}{*}{$\begin{array}{l}\text { Domineering attitude } \\
\text { towards MOs }\end{array}$} & NMS & $\begin{array}{l}\text { The MOs should seek suggestions from } \\
\text { NMS when classifying leprosy }\end{array}$ & \multirow[t]{8}{*}{90} & \multirow[t]{8}{*}{ Negative } \\
\hline & & $\mathrm{HE}$ & $\begin{array}{l}\text { The MOs should seek suggestions from } \\
\text { health educators when arranging health } \\
\text { education. }\end{array}$ & & \\
\hline & & LI (TN) & $\begin{array}{l}\text { The MOs should seek suggestions from LI } \\
\text { when classifying leprosy. }\end{array}$ & & \\
\hline & & NMA (AP) & $\begin{array}{l}\text { The MOs should seek suggestions from } \\
\text { NMA while classifying leprosy. }\end{array}$ & & \\
\hline & & $\mathrm{PT}$ & $\begin{array}{l}\text { The MOs should seek suggestions from } \\
\text { physios regarding deformity assessments. }\end{array}$ & & \\
\hline & & LT & $\begin{array}{l}\text { The MOs should seek suggestions from } \\
\text { lab. technicians when reading smear } \\
\text { reports. }\end{array}$ & & \\
\hline & & Nurse & $\begin{array}{l}\text { The MOs should seek suggestions from } \\
\text { nurses when treating in-patients. }\end{array}$ & & \\
\hline & & Pharm & $\begin{array}{l}\text { The MOs should seek suggestions from } \\
\text { pharmacists when prescribing medicines. }\end{array}$ & & \\
\hline
\end{tabular}

